\title{
Our Pet Chipmunk
}

\author{
Mrs. F. Bilsbury
}

$W^{\mathrm{E}}$

LL, all you young people will by now want to hear more about the various pets that we have had. Peter is still about the farm with several other rabbits. He will sit quite still when we call him. Johnnie is free to swim all over the large slough and we think he has set up housekeeping.

But now for the story of our last pet, and I think the one we loved best of all. Why?-because he was crippled and so very patient. One cold, dull, very damp day, Gary and Aletha came from school in great excitement. "Guess what we have in our lunch kit?" Of course I guessed all wrong. After some fumbling among lunch papers, I was handed a very tiny, very dirty, chipmunk. "He is hurt so maybe you can sort of fix him up mother." This from my two hopefuls. Well I washed him and discovered that one side of his face was torn off-the upper portion from his eye to his nose. We made him a nest in an old homemade bird cage with fine sweet hay and some soft rags which he soon arranged to suit himself.

Every day I dressed his sore face and never once did he struggle or try to bite. He was unable to utter any sound other than a faint sort of whistle. He loved Aletha best of all, and would scamper along her arm to her shoulder and up on top of her head, where he would peep from her curls with his one good eye - the other was blind. He showed the urge to store food by stuffing what he did not eat in his one cheek and then appealing to someone to carry him to his box. He knew his name which was "Chippie" and would come at once when called.

He slept a great deal for a time but did not hibernate. His table manners were excellent so he was allowed on the table at breakfast time. There he was given one teaspoon of milk and a large saskatoon. He had oats in his box.

Well, I am sorry to say that when the spring break-up came he began to fail and his old injury took over. He became totally blind in his one good eye. The torn part of his face became very bad and he lost more skin around the eye. He seemed so cold and wanted someone to hold him in his hand. Then one morning we found him curled in his nest, dead. We miss him still, as he was such a lovely little fellow throughout the six months or longer that we had him

Perhaps in a future letter to you I will tell about the House Sparrow who sang.

\section{Bird Chatter}

By E. K. Jones, Raymore.

7 THE BIRD HOUSE built last spring for the Bluebirds has recently been taken over by the House Wrens, who have just hatched their young. Such busy little birds they are chirping and scolding everyone who passes.

A Great Blue Heron was seen on our dugout, August 24-a rather shy individual.

I was shocked to read that $\mathrm{Mr}$. Knox, of Clair, has such a dislike for. the Catbird. Although it does upset other birds' nests, I do not feel that it should not be admired. The plumage and song of the Catbird is one of the finest sights and sounds ever to be heard.

\section{The Naturalist's Library}

HANDBOOK of NORTH DAKOTA

North Dakota Agricultural College, Fargo, N.D., 324 pp., 308 illustrations, 1950. Price $\$ 4.50$. This manual provides keys and descriptions to all the flowering plants and ferns, totaling 1143 species, known to occur in North Dakota. It is a most useful book to those seriously interested in the vascular plants of North Dakota and adjacent regions of the United States and Canada. 